\title{
Nationalised large-scale mining, trade unions and community representation: perspectives from Northern Madagascar \\ Article
}

Accepted Version

Smith, S. and Dorward, P. (2014) Nationalised large-scale mining, trade unions and community representation: perspectives from Northern Madagascar. Resources Policy, 40. pp. 31-41. ISSN 0301-4207 doi:

https://doi.org/10.1016/j.resourpol.2013.11.006 Available at https://centaur.reading.ac.uk/35643/

It is advisable to refer to the publisher's version if you intend to cite from the work. See Guidance on citing.

To link to this article DOI: http://dx.doi.org/10.1016/j.resourpol.2013.11.006

Publisher: Elsevier

All outputs in CentAUR are protected by Intellectual Property Rights law, including copyright law. Copyright and IPR is retained by the creators or other copyright holders. Terms and conditions for use of this material are defined in the End User Agreement.

www.reading.ac.uk/centaur 
Central Archive at the University of Reading

Reading's research outputs online 


\section{Nationalised Large-Scale Mining, Trade Unions and Community Representation: Perspectives from Northern Madagascar}

Shirley M. Smith and Peter T. Dorward

School of Agriculture, Policy and Development, The University of Reading, P.O. Box 217, Reading, Berkshire, RG6 6AH, UK.

\section{ABSTRACT}

This article critically explores the nature and purpose of relationships and interdependencies between stakeholders in the context of a parastatal chromite mining company in the Betsiboka Region of Northern Madagascar. An examination of the institutional arrangements at the interface between the mining company and local communities identified power hierarchies and dependencies in the context of a dominant paternalistic environment. The interactions, inter alia, limited social cohesion and intensified the fragility and weakness of community representation, which was further influenced by ethnic hierarchies between the varied community groups; namely, indigenous communities and migrants to the area from different ethnic groups.

Moreover, dependencies and nepotism, which may exist at all institutional levels, can create civil society stakeholder representatives who are unrepresentative of the society they are intended to represent. Similarly, a lack of horizontal and vertical trust and reciprocity inherent in Malagasy society engenders a culture of low expectations regarding transparency and accountability, which further catalyses a cycle of nepotism and elite rent-seeking behaviour. On the other hand, leaders retain power with minimal vertical delegation or decentralisation of authority among levels of government and limit opportunities to benefit the elite, perpetuating rentseeking behaviour within the privileged minority. Within the union movement, pluralism and the associated politicisation of individual unions restricts solidarity, which impacts on the movement's capacity to act as a cohesive body of opinion and opposition. Nevertheless, the unions' drive to improve their social capital has increased expectations of transparency and accountability, resulting in demands for greater engagement in decision-making processes.

\section{Key Words:}

Community representation; Corporate Social Responsibility (CSR); Developing country; Development; Extractives Industry Transparency Initiative (EITI); Governance; Large-scale mining; Madagascar; Minerals; Nepotism; Rent-seeking; Resource rich; Sub-Saharan Africa; Unions 


\section{Introduction}

This article contributes to the debate on community development in the extractives industries, focusing on the challenges associated with the concept of stakeholder engagement in decision-making processes, as required by initiatives, such as the Extractive Industries Transparency Initiative (EITI). The EITI is an externally validated voluntary scheme aiming to nurture "good governance" through improved transparency and accountability in countries dependent on revenues from extractives industries. ${ }^{1}$ One key principle is the engagement of a well-informed stakeholder group comprising governments, companies and civil society (Extractive Industries Transparency Initiative Secretariat, 2008, Department for International Development, 2006). The underlying question, however, is whether the trend towards community engagement in such processes is, in reality, effectively contributing to the desired rhetoric of good governance by improving accountability and demanding greater transparency? ${ }^{2}$

Moreover, the focus on mineral extraction as a vehicle for economic growth in resource-rich developing countries is controversial on account of questionable economic and poverty alleviation benefits, as well as the direct environmental and social impacts. Notably, reliance on tax revenues from mineral exports is associated with conflict, corruption and rent-seeking behaviour - a paradox, known as the 'Resource Curse'. ${ }^{3}$ As a consequence, the World Bank's ongoing support for mineral extraction as a vehicle for socio-economic development has attracted criticism (see e.g. Auty 1993; Karl 1997; Pegg 2003). Nevertheless, many resource-rich developing countries have embarked on a strategy of expanding the extractives sector, ostensibly to fund economic and social development plans. Associated mining reforms and relatively untapped mineral reserves have catalysed the growth of the

\footnotetext{
${ }^{1}$ The term 'good governance' is subjective and complex to define, although It is typically described in terms of the mechanisms considered necessary to achieve a certain quality of governance, such as embracing participatory processes as an essential component to improve transparency and accountability in the extractive industries (Hobley and Shields 2000; Hyden et al. 2003).

${ }^{2}$ In developing countries, 'good governance' is commonly linked to the concept of participation as an essential component of achieving accountability (Hobley and Shields 2000).

${ }^{3}$ In the context of resource revenues, rent-seeking refers to the impact of natural resources on the behaviour of private agents, groups of agents or agencies and the motivation for their actions. In other words, rent-seeking is motivated by the potential financial gain from large resource revenues and manifests as economically inefficient decision-making by government officials pursuing selfinterests (Kolstad and Wiig 2009).
} 
mining sector in sub-Saharan Africa in particular. In addition to recent rapid sector growth, predominantly through trans-national corporations, Madagascar has a longestablished chromite mine, which provides historical and parastatal perspectives to the controversy surrounding the impacts of the extractives industries on community development.

The fieldwork for this research was conducted in Madagascar in June 2009, shortly after violent civil unrest had precipitated the resignation of President Ravalomanana. ${ }^{4}$ The circumstances surrounding his downfall included widespread concerns about land acquisition for both large-scale mining and agricultural use by foreign companies. For instance, the allocation of 1,300,000 hectares of arable land to Daewoo Logistics to produce palm oil and corn for export was considered an excess and abuse of power (Vinciguerra 2010; Andrianirina-Ratsialonana et al. 2011; IRIN Africa 2012). ${ }^{5}$ Ravalomanana was accused of 'selling off' ancestral land to the South Korean company without due regard for informal land ownership, particularly untitled unoccupied pastoral lands. Furthermore, the workforce was to be predominantly South African, fuelling concerns about the absence of employment opportunities for Malagasy people and equivocal added-value to local communities. In 2009, the Daewoo land lease was revoked by the Haute Autorité de la Transition (Transitional High Authority: transitional government) (after Pearce 2012). Although President Ravalomanana's exit marked the end of a seven year period of relative political stability, many citizens considered it the rightful deposing of a corrupt president. $^{6}$

The circumstances surrounding land disputes are reflected in the literature regarding the country's governance systems and processes relating to forest management and biodiversity. Authors have identified imbalances in community representation that impact on the equity of access to common pool resources and which diminish respect for traditional governance. For example, often motivated by the

\footnotetext{
${ }^{4}$ In March 2009, Ravalomanana handed power to a military directorate who immediately passed the country's leadership to Andry Rajoelina, the former Mayor of Antananarivo, and a transitional government (Haute Autorité de la Transition: High Transitional Authority) (Ploch 2009).

${ }^{5}$ The extent of the deal can be more easily contextualised when compared to the area of arable land currently exploited: Daewoo were to lease an area equivalent to more than half of the country's estimated 2,500,000 hectare of exploited pastoral land).

${ }^{6}$ Presidential elections have been repeatedly postponed, although the first round was held on October 25th 2103 BBC. (2013). "Madagascar holds long-awaited presidential elections." Retrieved 25th October, 2013, from http://www.bbc.co.uk/news/world-africa-24661607.
} 
privatisation and commercialisation of natural resources, rural communities are excluded from the resources that form the basis of their livelihoods (Ramamonjisoa 2010). Furthermore, the powerful influence of external actors in policy-making decisions, such as private operators, non-governmental organisations, donors and the state, facilitates the exclusion of poor rural communities and the subordination of their traditional activities (Huff 2010; Smith et al. 2012). Poor communication and a lack of information from policy-makers and implementers further marginalise the poor communities likely to be affected by those policy decisions (Talbot 2010). In essence, community voices are rarely invited to the negotiating table and infrequently heard in policy debates on conservation governance in Madagascar where, increasingly, the 'rich' have the power to marginalise the 'poor's' access to resources (after Beck and Nesmith 2001).

This paper aims to explore the validity and authority of community representatives selected to engage in decision-making processes, particularly in light of the growing global trend for community stakeholder engagement as a means of strengthening governance. For instance, a key principle of the EITI is the engagement of a broad stakeholder group - comprising governments, companies and civil society - with the aim of achieving greater transparency and accountability (Department for International Development 2006; Extractive Industries Transparency Initiative Secretariat 2008). The paper commences with an overview of mineral code reforms and an outline of large-scale mining in Madagascar to introduce the case study company and the union movement therein. Within the context of resource-rich developing countries experiencing political instability, the findings of the data analysis contextualise the challenges of community representation and the implications of using stakeholder engagement as a means of improving governance. The discussion explores influences within the interactions associated with the extractives industries, situating them in the broader literature to offer a global perspective on the findings.

\section{Mining codes and reforms}

The evolution of mining codes in sub-Saharan Africa is associated with the structural adjustment and trade liberalisation programmes advocated by the World Bank to attract FDI, in the climate of significant debt experienced by many developing countries in the 1970s. Much has been written about the impacts of structural adjustment programmes, but very little attention has been paid to the consequent trade liberalisation and privatisation of state enterprises, particularly in the mining sector. In effect, these liberalisation policies assume considerable importance, as they form the basis of the long-term relationships between resource-rich governments and trans-national mining companies. 
Campbell (2003) notes that three generations of mining codes have developed in response to trends in governance and economic structural adjustment. The first generation reflects the World Bank's liberalisation strategy of privatisation and state deregulation of the mining industry. The accompanying reforms stimulated a mining boom; yet, in Ghana, positive impacts were limited at the local and national level, due to most foreign exchange earnings being invested, and remaining, offshore. Second generation codes emphasise capacity-building and good governance through institutional reforms, whilst retaining the earlier concept of state deregulation which places responsibilities largely on the private sector. Nevertheless, second generation codes fail to address the statutory control of environmental impacts or the allocation of revenues towards sustainable development. Moreover, the mechanism to effect self-regulation was unclear, particularly in a political, social and market environment with a weak institutional framework unaccustomed to intense public scrutiny. Guinea's code, for example, initially based on the principle that improved environmental management leads to social and economic development, subsequently evolved to prioritise economic growth rather than sustainable development. The underlying implication is that any negative impacts of mineral exploitation would be tolerated to accommodate economic growth (Campbell 2004).

This combination of poor public scrutiny, limited state intervention and the pressure of competitive markets in the mining sector has been linked to increased poverty, which impedes progress towards the goal to achieve sustainable social and economic development (Campbell 2004). Third generation codes aim to address such problems by incorporating the engagement of stakeholders in the consultative process and reintroducing state regulation. Although mining codes overtly aim to improve governance, the experience of most developing countries suggests that this aim is over-shadowed by the drive for FDI. For instance, in Tanzania, driven by external financial pressures during a period of extreme debt, the code was heavily influenced by the objective to establish a risk-free investment climate (Butler 2004). Considered to be a third generation code, Madagascar's Document Cadre de Politique Minière (Mining Policy Outline Document) sets out environmental legislation to protect the high level of endemic species in the country and formally adopts the concept of stakeholder engagement as a means of consultation. In common with Ghana, Guinea and Tanzania, motivated by high external debt and the drive for a high growth economy, Madagascar introduced fiscal conditions, including low duties and revenue rates, to attract FDI in its growing mineral industry with the ostensible goal of poverty reduction and environmental protection. Sarrasin (2009: p. 155) argues that: "It is precisely the consequences of such policies that the EIR (Extractive Industries Review) addressed, questioning the effects of liberalisation on the legal framework, on poverty and the environment", noting that the lack of public 
scrutiny and weak institutional framework, typical of many countries in sub-Saharan Africa lowers a government's capacity to intervene. ${ }^{7}$ Butler (2004) adds that financial dependence on FDI further weakens a government's opportunity to negotiate. Thus, Madagascar's heavily indebted economic status and the outcome of structural adjustment programmes are likely to leave the government in a weak position with regard to negotiating with external investors, such as Rio Tinto and Sherritt. ${ }^{8}$ Despite these criticisms, the World Bank continues to drive liberalisation and privatisation. Based on models established in Latin America, the Bank provides loans, guidance and expertise to countries embarking on legal, fiscal and regulatory reform in their extractives sector (Butler 2004).

Madagascar is a recipient of ongoing World Bank loans to finance regulatory and governance reform in the mineral sector (see World Bank 1998; 2002; 2003; 2008). The country's trans-national large-scale mining industry is relatively new, thus, studies are yet to examine its impact on the local economy. However, experience from the aforementioned ill-fated Daewoo land deal suggests that improving social conditions through developing local employment opportunities was not integral to the then-Government's agenda for attracting FDI. The country's rapid mineral industry growth supported by World Bank loans aimed at attracting FDI combined with the statutory disempowerment observed in other developing countries provide further reasons for conducting this study in Madagascar.

\section{Large-scale chromite mining in Madagascar}

The location for this study is the country's first chromium mine, which was opened at Bemanevika in 1968 by Compagnie Minière d'Andriamena (COMINA); a joint venture between the French group (PUK: Pichiney Ugine Kullman) with 20 per cent Government of Madagascar ownership. In 1975, during the socialist period in Madagascar's political history, COMINA was nationalised and the name changed to Kraomita Malagasy S.A. or Kraoma as it is commonly known and referred to hereafter. The company's website cites Kraoma as a limited company belonging entirely to the state, with an authorised capital of 3,231,560,000 MGA (US\$ 1.4

\footnotetext{
${ }^{7}$ In response to criticism of its support for mineral extraction, the World Bank commissioned the Extractive Industries Review (EIR), which is also critical and recommends that the Bank requires countries to meet specific criteria before providing financial support to extractive projects (World Bank 2004).

${ }^{8}$ Rio Tinto and Sherritt projects were the most advanced at the time of this study.
} 
million), ${ }^{9}$ although it ambiguously also states that "the State owns the majority of shares in the company" (Kraomita Malagasy S.A. 2010). ${ }^{10}$ Madagascar's EITI report for 2011 clarifies that the company is a 75:25 public-private partnership between the Ministère de l'Energie et des Mines (Ministry of Energy and Mines) and two financial partners, SONAPAR and Ny Havana (2007; Ernst \& Young 2011: p. 10). ${ }^{11}$

Kraoma operates in Betsiboka Region, which is rich in exploitable minerals, notably gold, gypsum and chromium. Artisanal gold mining has occurred for decades in Maevatanana District within Betsiboka. Gemstones and semi-precious stones occur in the south of the Region; however, very little information is published regarding their exploitation potential (Région Betsiboka undated). The communes of Briéville and Andriamena, Kraoma's area of operation, are logistically isolated from Betsiboka Region's administrative centre, Maevatanana, by the limited road infrastructure and geographically separated by the Tsaratanana Massif, which contains the highest mountains in the country. Antananarivo, the country's capital, approximately 400 kilometres south of Briéville is more accessible than the regional centre. The cosmopolitan mix of Malagasy ethnicities around Andriamena/Briéville has remained relatively constant since the French-established mining company was nationalised in the 1970s. Communities evolved around mineral exploitation; both the large-scale chromite exploitation and artisanal gold mining attracted in-migrants from across Madagascar, expanding both rural and urban communities. Briéville is one of the largest communes in the Region, with a population of 14000 (Cornell University 2002). Briéville town has approximately 3500 residents - all Malagasy except for one expatriate - of whom 350 are directly employed by Kraoma. ${ }^{12}$

\footnotetext{
${ }^{9}$ Ostermiller, S. (2013, 5th October 2013). "Calculator for United States Dollar." Currency Exchange Rate Conversion Retrieved October 5th, 2013, from http://coinmill.com/MGA_calculator.html.

10“L'État possède donc la majorité des actions de la société” - translated by the author.

${ }^{11}$ SONAPAR: Société Nationale de Participation Et De Placements, an official investment agency. NY HAVANA Assurances \& Reassurances Sobika. (2011). "Ny Havana." Guide Services Retrieved 1st October 2011, 2011, from http://www.sobika.com/sofitrans-nyhavana.html.

12 Madagascar is administratively divided into Regions, Districts, Communes and Fokontany; the latter being the lowest level, roughly comparable to a parish in the UK. In this article, a distinction is made between Briéville town and Briéville commune. Briéville town refers to the urban centre; Briéville commune refers to the administrative area comprising the town and rural fokontany.
} 


\section{Union movement in Madagascar}

The union movement is active in Kraoma, with six of the country's 13 unions represented there. Unions were initially established in Madagascar in the late 1930s by French colonialists, to support workers in the colony's developing agriculture and export sectors. Affiliation evolved around Christian, Socialist and Communist themes, similar to the French union structure at the time (Andrianasy and Groeger 2011). Prior to this, membership in French unions worldwide had been exclusively for Europeans (Bureau for Workers' Activities of ILO (ACTRAV-ILO) 2010).

In 1960, after Madagascar's independence, the union movement was granted legal status by the new Republic (2005: p. 204-205). However, during the Second Republic - from 1975 to the end of President Ratsiraka's first term in 1992 - unions experienced significant change, essentially being incorporated into the political system and having to align themselves with the socialist government. ${ }^{13}$ Exacerbated by the impact of economic liberalisation ushered in by structural adjustment policies, unions struggled to survive during this period and their membership declined considerably. In the 1990s, during the political liberalisation of the Third Republic, the union movement regained its independence (Andrianasy and Groeger 2011). Although several new unions were created and surviving unions regained their authority, the union movement's power and strength remain diminished and membership has not returned to pre-socialist era levels. Several authors have commented on the weakness of the union movement in Madagascar in the $21^{\text {st }}$ century, citing factors such as proliferation; poor internal organisation; difficulties in accessing the strong informal sector; and the unlawful obstruction of trade union activities in certain economic areas, such as the free trade zones and informal sector (2005; Fleischmann 2009; ITUC 2008). Unions have also accused the Ministère de la Fonction Publique, du Travail et des Lois Sociales (Ministry of Public Service, Labour and Social Law) of contributing to their disempowerment by selecting candidates for, and manipulating the outcome of, the elections for worker representatives to various tripartite bodies (ITUC 2008). However, few authors have explored the role and function of trade unions in the extractives industries in terms of their engagement and capacity to influence decision-making processes, as well as their potential role in stakeholder groups.

\footnotetext{
${ }^{13}$ Admiral Didier Ratsiraka initially gained presidential control as part of an interim military junta in 1975, retaining his position through two elections until losing to Albert Zafy in 1993, whom he subsequently defeated to regain the presidency in 1997.
} 
Highlighting the volatile political context at the time of the study, the introduction to this article aims to establish several key points: the challenges associated with community representation; the drivers for resource-rich developing countries to attract FDI, specifically in terms of mineral exploitation; the global emphasis on stakeholder engagement as a means of improving governance mechanisms; and the under-explored potential role of the union movement.

\section{Methodology}

The purpose of this study was to critically examine and explore relationships and interactions between the varied stakeholders at the grassroots, to test the thesis of engaging civil society as a means of achieving accountability and transparency in the pursuance of good governance in the extractives industries. The study explored the institutional and governance relationships between large-scale mining companies, government and local communities. Emphasis was placed on the social consequences and benefits to host communities associated with decision-making during the initial phases of the mining business cycle through to operational activities.

The research was structured to consider the interactions between social actors and their inherent impact or capacity to change social phenomena. Social constructivism forms the ontological basis for the study with an interpretive epistemological approach. Interviews were the preferred method of data collection as they facilitate the collection of peoples' experiences, thus, providing a more personal understanding of historical, current and future concerns. They also offer an opportunity to clarify and expand on answers through further questioning. The data analysis is based on the values and significance people place on their own and others' actions within social interfaces (after Grix 2002; Robson 2002).

The data mostly originate from 30 interviews and four focus groups conducted, in 2009, in the communes intrinsically linked to the government-owned, but privately managed mining company, Kraoma. However, 26 interviews with 32 key informants had previously been conducted in Antananarivo, the country's capital, to gain strategic policy data. ${ }^{14}$ Rural communities were purposively selected using the criteria of villages currently economically dependent on Briéville commune, although it should be noted that this did not exclude any of the neighbouring communities. Interviews were conducted with the assistance of a native Malagasy interpreter

\footnotetext{
${ }^{14}$ Some interviews were conducted with more than one respondent.
} 
fluent in the local dialect; all interviews were recorded and then fully transcribed.

The interviews were conducted to enable a discourse flow from respondents amidst the active translations necessary to ensure all parties properly understood the ongoing dialogue.

The mining project is the only large-scale employer in the location; thus, the level of risk posed to respondents participating in the study was assessed prior to interview. The study objectives respected the rights of respondents in terms of their relationship with other stakeholders (after Kent et al. 2002). However, very few respondents expressed concern about discussing controversial or sensitive issues, possibly on account of the anonymity offered and the climate of openness which accompanied the presidential coup. Pre-interview discussions were held with the mining company and key rural figures to explain the aims and objectives of the research, and to confirm confidentiality of response, thus, respecting hierarchical structures of permission in Malagasy society.

The breadth of potential stakeholders in this location is constrained. Few small and medium businesses exist around Briéville, only one non-governmental organisation is active and no regional government departments are present. Notably, the ethnic diversity within the community is higher than in most locations in the rest of the country. Community respondents were selected from a heterogeneous social group spanning a range of social classes and ethnicities. The ages of these people ranged from early-20s to early-80s and included small retailers, teachers, religious leaders, farmers and a traditional leader, as well as a mayor and several présidents fokontany or vice-présidents fokontany (elected representatives of unique administrative areas and their deputies). ${ }^{15}$ A number of women were purposively selected for interviews in the retail sector and community respondents. Women freely participated in mixed sex focus groups; thus, single-sex focus groups were not conducted. Women have a comparatively equitable status in many central highlands tribes - a case in point being that, pre-colonisation, a queen often headed Merina royalty (Graeber 2007). ${ }^{16}$

Data were analysed using both coding and non-coding methods. Codes originating from the initial research questions were manually applied to transcripts, and then

\footnotetext{
${ }^{15}$ Constitutionally, mayors, présidents fokontany and their deputies are elected by universal suffrage.

${ }^{16}$ The Merina tribe, concentrated in the Central Highlands around Antananarivo, politically dominated the island prior to colonisation by the French.
} 
interrogated and sorted to identify themes. To broaden the analysis capacity and to maximise the flexibility of the qualitative data, a non-coded iterative process of interview transcript review was also undertaken. Themes identified in each transcript were subsequently collated and summarised within and across each stakeholder group to determine the key patterns.

\section{Findings}

To explore the challenges of community representation and the implications of using stakeholder engagement as a means of improving governance in resource-rich developing countries experiencing political instability, the findings contextualise the relationships between the varied stakeholders. They are presented under the following themes: 1 ) social context and employment profile in the location; 2 ) relationships between Kraoma and the wider community; 3) community representation; and 4) key players and institutions in a business context.

\section{Social context and employment profile}

Exploring the social profile in the location provides an insight into communities, their institutions and representatives, issues which are critical to the identification of key players and institutional arrangements at the interface between mining and society. Prior to the development of commercial chromite mining in the 1960s (as outlined in the Introduction), the area comprised indigenous communities and established groups of Malagasy in-migrants attracted to the plentiful uncultivated agricultural land and artisanal mining activities. As the large-scale mining operation developed, in-migration increased. Rural in-migrant respondents described the various motivations for their families' move to Briéville and Andriamena: to engage in the artisanal gem and gold exploitation, which has continued to grow since the 1940s; to find a sustainable livelihood through good agricultural land outside their homeland in under-populated rural grasslands; or the desire to make a living supplying produce to the flourishing new mining community. As one elderly villager explained during an interview:

I arrived here in $1942 \ldots$ There was no company at that time. People were just looking for gold and then precious stones: crystal and amethyst. People did nothing other than grinding rice to be sold in Morarano (neighbouring commune]... Men and women walked a long way - for three days - carrying 
the rice and they only got $10 \mathrm{FMG}[2 \mathrm{MGA}]$ for five boxes [70 kilograms] ${ }^{17}$ (Briéville, June 2009).

Older rural respondents spoke about the gradual evolution of employment opportunities over time, from manual work through to semi-skilled labour. During an interview, an elderly 'newcomer', ${ }^{18}$ who had moved to the area prior to the establishment of commercial chromite extraction, summarised the evolution of employment opportunities from the start of the construction phase in the 1960s:

Kraoma [at the time of COMINA ownership] invited people to come and work [for them]. Because people had little education, they got manual work and labouring. Quite a lot of people [got jobs] because it included road building [and they needed lots]. Some of them worked until retirement. [Once the road was built] some of those people with a little education worked for Kraoma, but manual jobs. They started to learn new things... Some of them became mechanics or drivers (Briéville, June 2009).

However, this study found that the majority of Kraoma's employees were recruited from the urban community, who are predominantly "newcomers". Each rural fokontany (parish) visited during the study reported only two or three men employed by Kraoma and a similar number who had retired and returned to the village to resume farming activities on family land. ${ }^{19}$ Even with the appropriate educational qualifications, recruitment practices seemed to discriminate against rural men. ${ }^{20}$ One suitably qualified rural respondent cited nepotism as a factor in his difficulty in gaining employment. A respondent closely linked to Kraoma confirmed that urban children of workers received preferential treatment, although "not every son gets a job" (Briéville, June 2009). A rural male would be unlikely to be employed

\footnotetext{
1710 FMG (Malagasy Franc - currency pre-1961, although still commonly referred to in conversation)= $2 \mathrm{MGA}$, (Malagasy Ariary - current currency) which is equivalent to $1 / 10^{\text {th }}$ of a US cent. Rice is commonly measured in boxes: 1 box = approximately 14 kilograms.

${ }^{18}$ Settled families refer to themselves as 'newcomers', regardless of the date of their arrival; the most established 'newcomer' respondent arrived as a small child in 1942.

${ }^{19}$ Employees from rural villages generally moved to town with their children in order to benefit from Kraoma's housing, education and welfare facilities, often returning to the villages at weekends to farm family land or, in some cases, to visit second wives.

${ }^{20}$ The minimum standard is BEPC: (Brevet d'Études du Premier Cycle) a French educational qualification (although no longer used in France), which most closely equates to GCSEs (General Certificate of Secondary Education) in the UK.
} 
unless his father had retired from Kraoma. These discriminatory employment practices resulted in departments recruiting from the same fokon'olo (kinship group) in the urban community. ${ }^{21}$ Thus, ethnic grouping and hierarchies were observed in the employment profile.

Kraoma employs very few females in Briéville town; thus, formal employment opportunities for women are limited. A small number of women worked in the government health clinic or as teachers at either urban or rural government schools. Females, however, dominated the small retail sector, working in the pharmacy as well as self-employed in small shops and stalls in the market. One key respondent estimated that approximately 30 women had formal salaried employment in Briéville: less than one per cent of the town's population. As a consequence, the majority of women in town were unemployed, bored and lacked motivation. In 2007 , in an attempt to rebalance the poor social skills exhibited by women in Briéville town, a women's association was established by a few middle class women associated with Kraoma. Social problems manifested as arguments escalating into physical fights between women and a degree of child neglect. The low educational level of female community members, compared with mining communities in other countries, and poor motivation due to a lack of job opportunities were thought to be causal factors, exacerbated by some stereotypical male behaviour: polygamy, alcohol abuse and failure to provide wives with money. Initial meetings focused on basic social skills; dressmaking and cooking were also offered, in an attempt to expand livelihood potential. Those sharing their skills, however, struggled to balance the wider benefits of altruism against their direct loss of earnings. In common with several associations encountered in this study, members' enthusiasm waned on realisation that they had to actively participate in the association rather than passively benefit from other people's actions. Membership had halved by 2009 and, despite verbal support for the initiative and (broken) promises of lambahoany (traditional sarongs), Kraoma provided no funding for the association.

\section{Relationships between Kraoma and the wider community}

In a broader context, the company's economic and political capital has facilitated the evolution of a paternalistic relationship with both rural and urban communities. ${ }^{22}$ Kraoma is the only large employer in Briéville commune and provides the majority of

\footnotetext{
${ }^{21}$ In the context of multi-cultural Briéville, fokon'olo refers to people with shared ethnicity or kinship.

${ }^{22}$ In this context, paternalism is used to describe the hierarchical relationships that have developed between the company, its workers and neighbouring communities.
} 
housing, services, utilities and schools in the town. It assisted with the construction of four churches and a new classroom at the public high school, as well as funding the Alliance Française (French cultural centre). A senior manager in Kraoma summarised the relationship between Kraoma and wider society during an interview:

In Briéville, Kraoma is in charge of everything, including medical care. ${ }^{23}$ The houses belong to Kraoma; the Catholic and Protestant churches were built by Kraoma... We run kindergarten, primary and junior high schools. ... [there is a] tight interdependence and interaction between society and [the company]... This town exists because of Kraoma. Most, maybe 95 per cent, live on activities linked to Kraoma. It is a very cosmopolitan town; all the tribes in Madagascar are represented here. [Note: Only one expatriate resident in town.] They came here to work. ...it makes Briéville unique compared to other cities. Also the company pays royalty taxes... that are used for things like building the new market. Even the neighbouring communities depend on Kraoma. Local peasants provide produce etc. to sell to Kraoma and its employees. ...Kraoma also provides the light, electricity and water (Briéville, June 2009).

Kraoma's Service Cité (maintenance department) extended beyond responsibility for employees' housing, operating as a profit-making business. In the absence of any private maintenance or service companies in town, Service Cité would work on nonKraoma property and invoice the owner. It was unclear whether Kraoma had adopted a strategy to exclude private ventures, or had been compelled to fill a gap in the market on account of the general lack of skills and initiative within the community.

Although Kraoma does not have a formal corporate social responsibility programme extending beyond the welfare of employees, exploration and observation of the relationships between Kraoma and the community in the company's catchment area identified clear paternalistic tendencies. When asked about Kraoma's development activities in the area, a senior manager offered examples of infrastructure improvements and pastoral care:

We made the road, firstly for our benefit, but Briéville commune also profits. The Alliance Française [which Kraoma funds] - everyone can go there to

\footnotetext{
${ }^{23}$ Kraoma provides healthcare for employee families; however, a state health clinic provides primary care for non-employees.
} 
improve their communication skills. Kraoma has a clinic and everyone can have a consultation there. Everything isn't free, sometimes you have to pay for medicines, but everyone can benefit. In addition, the company ambulance can be used to transport people to the hospital at Ambatondrazaka. There are also HIV testing facilities at the clinic (Antananarivo, June 2009).

Arguably, the in-migration of farmers to the area since the 1960s indicates the perceived positive impact of Kraoma on rural livelihoods. ${ }^{24}$ Farmers were attracted to the availability of non-cultivated land and the expanding urban market of Briéville residents. Many expounded the opportunity to settle and invest in land, although land ownership for some 'newcomers' is contentious. ${ }^{25}$ Indigenous farmers also benefitted, increasing their yield to sell produce to the urban community.

In an urban setting, however, greater criticism was directed at Kraoma and their dominance over both local government and the wider community, particularly with regard to their influence in decision-making processes. Unequivocally, Kraoma is the most powerful actor in Briéville commune. Despite being a public-private partnership, the company is considered state-owned, which affords it considerable control over strategic decision-making processes, essentially subordinating local and, the mostly absent, regional government. Moreover, Kraoma's payment of royalties to the commune has enabled urban Briéville to develop beyond similar sized communes elsewhere and has led to local government dependency on Kraoma. From a broader perspective, Kraoma's presence is also the catalyst for the area's development; however, no significant regional or national government development programmes were identified in the commune.

\footnotetext{
${ }^{24}$ The company was established in the 1960s.

${ }^{25}$ The Government's policy of formalising land ownership had created conflict between indigenous communities and 'newcomers' in the area. Some 'newcomer' communities had encountered difficulties registering land ownership, despite having occupied and farmed land for over 40 years. In an interview, a 'newcomer' who arrived in the mid 1970s explained the source of the disharmony: "Land that was obviously not being used - 'newcomers' started to exploit it, then afterwards (indigenous) people claimed it" (Briéville, June 2009).
} 
Community representation: local government, traditional governance and ethnic associations

Local government elections in Madagascar are tainted with irregularities and political manipulation, which create hierarchies of dependency and the effective suppression of opposition (Smith et al. 2012). Within the local government hierarchy, the Chef de Région (Regional Head: the government representative at regional level) is the key actor. ${ }^{26}$ Constitutionally, local government officials are elected posts; however, if elections are held, they are routinely 'stage-managed'. Mayoral elections in Briéville and Andriamena communes had been controversial, attracting accusations of candidate list manipulation. ${ }^{27}$ Several respondents accused the Chef de Région and Chef de District (Regional and District Heads) of bullying rural communities into voting for the 'preferred' candidate, to ensure the political homogeneity of postholders. The relationship between Kraoma and Briéville's Mayor was described as close. One respondent succinctly remarked in an interview: "The Mayor doesn't work for Kraoma, but it makes no difference. You don't have to work for Kraoma to be influenced by their power" (Briéville, June 2009). Conversely, présidents fokontany elections were generally considered fair, although vice-présidents fokontany were politically appointed in certain locations. ${ }^{28}$ Notably, this political manipulation of government officials creates dependencies which manifest as an unwillingness or incapacity to address non-compliance or the ineffectiveness of others within the cycle of dependency, resulting in a culture with low expectations of individual accountability. With specific relevance to the subject of stakeholder engagement in good governance initiatives, this can manifest as the suppression of community voices with regard to opposing and expressing concerns about the influence of the mining company or local government strategy.

Furthermore, the sanctity and autonomy of traditional governance in Madagascar are visibly diminishing under the influence of external governance and modernisation in resource-rich locations (Smith et al. 2012). In Briéville commune,

\footnotetext{
${ }^{26}$ Since their establishment in 2004, no elections have been held for any Chef de Région in the country; individuals have been appointed by the President according to political alliance and personal preference.

${ }^{27}$ The Mayors of Briéville and Andriamena communes, like many others, had overtly supported and been supported by Ravalomanana's political party, Tiako I Madagaskara (TIM) - Malagasy for "I love Madagascar", in the elections in 2007.

${ }^{28}$ Présidents and vice-présidents fokontany are elected representatives of unique administrative areas known as fokontany (parishes).
} 
however, traditional governance has evolved an almost unique context. In the early stages of urban expansion, ethnic groups with sizeable communities acted positively to strengthen their identity by establishing associations to aid with the protection of cultural norms, particularly those associated with death or marriage. ${ }^{29}$ The associations' roles had evolved into intervening in family disputes within the same ethnic group and mediating in disputes between different tribes. Although the associations were mostly described in the context of funerals, in effect, they had vicariously assumed the responsibilities of traditional elders. Several associations had appointed an elder, although his role was considered more a contribution to moral well-being than traditional governance. In summary, although ethnic associations exhibited considerable internal solidarity and the capacity to enhance social capital through unifying fokon'olo (kinship groups), they had few horizontal or vertical linkages and their political capital was minimal beyond kinship boundaries.

Traditional governance was more overtly recognised in the rural indigenous community visited in Andriamena; more remote from Briéville and, thus, diminished Kraoma's influence. The Tangalamena's (traditional and cultural leader) advice was sought regarding auspicious dates for important events, such as rice planting and marriages. ${ }^{30}$ One Tangalamena expressed serious concern about secession, citing the younger generation's limited exposure to events similar to those which acted as a catalyst in developing his inherent gift, compounded by diminishing interest in traditional culture. The testimony of this Tangalamena (traditional and religious leader) revealed a decline in the social and political capital of traditional governance. Certain traditions, however, remained steadfast. For instance, Kraoma acknowledged the significance of customary land blessings for new ventures by inviting the Tangalamena to conduct a traditional blessing ceremony at a newly opened mine. Although traditional institutions were stronger in the indigenous communities, their strength was gradually diminishing due to a variety of factors, including modernisation. Moreover, the mechanism whereby traditional leaders achieve their position on the basis of age and family links has created a deep-rooted

\footnotetext{
${ }^{29}$ Return to homeland and reconnection with ancestors is very important to Malagasy people after death; thus, the association helped fokon'olo (kinship group) members regain their spiritual home.

30 Tangalamena represent the tribe's royalty at a local level; their authority is bestowed on them at a fokon'olona, if they are judged to have the appropriate skills and experience. The ability to communicate with ancestors is essential, royal lineage is not. Literally, Tangalamena translates as 'red stick', referring to the wooden stick used to bless animals before their slaughter at traditional ceremonies. A Tangalamena has religious and civil importance, acting as traditional religious leader and the chief arbitrator for a group of families, thus, asserting his authority over family heads (Dez 1959).
} 
cultural issue regarding authority and accountability. Once leadership status has been achieved, the community accepts most decisions and actions without questioning accountability. This inherent low expectation of accountability and transparency has transferred across to administrative leaders, such as mayors and présidents fokontany, resulting in a disconnect between local government officials and communities. This practice fails to nurture a culture of good governance.

In addition to ethnic bonding, communities demonstrated the ability to form associations to improve human capital. For instance, parents directly employing teachers in unstaffed rural state schools, offering boxes of rice as payment; and the women's association established in town, although members and leaders were struggling to maintain enthusiasm and motivation. In certain fokontany (parishes), villagers also formed specific farming associations to improve economic capital; such as cattle breeding and cattle security. However, the authority of these grassroots associations remained within community boundaries; links to associations in other communities were not identified.

Multi-ethnicity in Briéville commune is a likely factor behind the fragmentation of society observed in urban and rural fokontany (parishes). Dialects and cultures are a common bond within fokon'olo (kinship groups), which can also sustain historical ethnic barriers, despite a cosmopolitan interaction with other ethnic groups. Influenced by the company's nepotistic employment practices, ethnic groups were also somewhat compartmentalised in the work environment. The broader rural community was similarly divisive, with a disconnect between 'newcomer' and indigenous villages, whereas relatively strong links existed within 'newcomers' of similar ethnic origin. The isolation from their homeland enhanced solidarity within rural fokon'olo, but increased fragmentation in the broader rural community. Ethnic solidarity was evident in situations where there were common issues, such as land disputes, since fokon'olo (kinship groups) would bond together to support its members in cross-ethnicity negotiations. The outcome of these circumstances is a fragmented and weak grassroots society, effective suppression of opposition and low expectations of accountability which manifests as community voices remaining unheard.

\section{Key players and institutions in a business context}

A key objective of the union movement in Madagascar is the economic and social progress of its members. Member and executive respondents from unions concurred that the movement's primary aim is to improve workers' social and economic rights, whilst safeguarding their employment through facilitating dialogue between workers, employers and the political administration. However, union 
executives alleged that the Government's failure to monitor or enforce statutory compliance with employment law, inter alia, served to weaken their position. They also expressed concern that the generally good dialogue between workers and management was not mirrored between union officials and government. The union movement is also susceptible to external political influence, as observed in the transitional government's influence on a union delegation from Kraoma. At the time of this study, union members were actively seeking the resignation of the Director General (DG), who had been appointed by the previous government under Ravalomanana. ${ }^{31}$ After an unfruitful meeting with the DG, in Antananarivo, for formal negotiations, the delegation made contact with members of the new Haute Autorité de la Transition (High Transitional Authority: transitional government), who allegedly proposed the removal of the DG from post. ${ }^{32}$ Disappointed by their unsuccessful negotiations with the DG, frustrated by the large number of high salaried senior managers at Kraoma's headquarters and fuelled by the recent political events, the delegation agreed to lobby for the DG's removal. This unilateral action by the delegation, without further consultation, created tension with some unions, depending on their political alliance. ${ }^{33}$ Nevertheless, unions within Kraoma represent a wide spectrum of views, opinions, ethnicities and political alliances, which are not suppressed by the political manipulation identified in local government. Personal development is a key motivator behind union membership and the findings of this study suggest that external capacity-building initiatives are creating a culture with greater expectations of transparency and accountability. It is noted, however, that union representation is limited to Kraoma workers and is not necessarily representative of wider society. Furthermore, this strength cannot be applied to trans-national large-scale mining operations with high numbers of expatriate workers. In these circumstances, any union representation would be allied to and recognised by the country of origin, thus, externalising the inherent and legitimate strength observed in unions in Kraoma.

\footnotetext{
${ }^{31}$ Former President Ravalomanana, ousted in 2009.

32 Established in the 1940s France, Comités d'Entreprise (company social committees), comprising elected worker representatives, received a percentage of employee wages to spend, typically, on health and welfare initiatives or to provide child support to workers' families (Bonin 2008). In 21st century Madagascar, it is a forum comprising employee and management representatives with the remit to participate in, be consulted about and influence decisions regarding the company's financial, operational and employment situation.

${ }^{33}$ Many unions have overt political alliances, often with ethnic allegiances.
} 
The most powerful union institution within Kraoma is the Inter-Syndicat (inter-union meeting), which comprises three Délégués de Syndicaux (union representatives) from each of the six unions represented in the company. Formal employeemanagement consultation is conducted through the Assemblée des Délégués du Personnel (employee representatives' meeting), which, in Kraoma, comprises union and management membership. ${ }^{34}$ Kraoma's unions were frustrated by the company's reluctance to establish a formal Comité d'Entreprise (company social committee). Legally endorsed in 2007, in companies with more than 50 employees, employee representatives have the right to request this formal forum for employee and management representatives. ${ }^{35}$ Respondents described a Comité d'Entreprise (company social committee) as more substantial than an Assemblée des Délégués du Personnel (employee representatives' meeting), extending beyond formal consultation to union engagement in decision-making on financial, operational and employment matters. A union executive foresaw that, in the context of mining, the Comité d'Entreprise (company social committee) could examine a company's accounts with a higher degree of transparency than other employee representative groups. Unions' positivity regarding these comités, however, is countered by employers' negativity. Some notable privatised companies had experienced considerable employee relations' difficulties after the establishment of Comités d'Entreprise: JIRAMA (water utility), SIRAMA (sugar producer) and Air Madagascar (national airline). At the time of this study, these companies were frequently experiencing negative publicity in the media, such as allegations of excessive salaries for their Chief Executives, many of whom are Westerners, or personal gain through corrupt means by Malagasy senior managers (Randrianasolo 2009).

Despite limitations, such as fragmentation of support through union proliferation, the impact of political alliances and external manipulation, unions are the most notable strength within society in Briéville commune. For instance, they exhibit the capacity to provide a platform within civil society where political opposition can be expressed and individuals can question the institutional structure in terms of accountability. One powerful characteristic is the freedom to associate at the grassroots without any obvious direct external political influence. Moreover, it is likely that the establishment of a Comité $d^{\prime}$ Entreprise (company social committee) in Kraoma would considerably enhance unions' rights within the company. In the context of the extractives industries, union involvement in the examination of a

\footnotetext{
${ }^{34}$ In non-unionised companies, the Assemblée de Délégués du Personnel would comprise employee representatives who are not union members.

${ }^{35}$ Comité d'Entreprise: translation taken from Bonin (2008: p. 10).
} 
company's accounts could improve transparency and accountability, conditions which proponents of the EITI believe will lead to good governance. The Comité d'Entreprise (company social committee), however, falls under Malagasy labour law and would not apply to the two most advanced (in terms of project development) trans-national mining companies operating in Madagascar, Rio Tinto and Sherritt, which have a predominantly non-Malagasy workforce.

\section{Discussion and Conclusion}

This study set out to identify the challenges associated with community representation in stakeholder engagement initiatives, through an exploration of grassroots relationships around the location of an established parastatal mining company. The aim was to examine the reality of the trend towards community engagement in decision-making processes as a means of improving accountability and transparency, in pursuit of achieving good governance in the extractives industries. The findings suggest that the key influence on community representation in Briéville commune is the paternalistic relationships between Kraoma, local government and wider society. In Briéville and Andriamena communes, the relationship between national and local government was characterised by political alliances arising out of electoral manipulation, which effectively suppressed community or political opposition. Local government is also effectively overshadowed by Kraoma's political and economic capital, in particular, the company's parastatal status and the commune's reliance on royalties. As a consequence of this dominance, few opportunities for broad consultation have evolved and there are no multi-stakeholder forums for strategic planning. In effect, local officials are heavily influenced by Kraoma; there is minimal focus on community involvement in the development of the town and even less focus on rural development. Thus, community representation is heavily suppressed by a variety of factors including political, financial and social capital. It is, however, acknowledged that Briéville town has developed beyond towns of similar size in other parts of the country.

The paternalistic relationship between Kraoma and Briéville's urban residents can be better understood by considering French industrial relations in the mid $20^{\text {th }}$ century and Kraoma's socialist roots in the mid-1970s. COMINA, Kraoma's French antecedent, almost certainly practiced racial paternalism in order to elicit a labour force, as well as broader paternalistic welfare institutions to attract Malagasy labour to under-populated Betsiboka Region (after Kelemen 2006). The latter type of paternalism was common in $19^{\text {th }}$ century France to encourage workers to relocate and settle in new areas. Typically, French mining companies invested the equivalent of up to 10 per cent of employees' wages in welfare provisions, such as housing, 
schools, churches, shops and medical care, as well as pension plans (Bonin 2008; Reid 1985). In Madagascar in the 1960s, COMINA's motivation was almost certainly to overcome the acute labour shortage and to provide suitable welfare facilities for the company's expatriate managers and families. After the departure of expatriates when the company was nationalised in 1975 during the socialist era, Kraoma maintained the welfare culture to support its Malagasy workforce, embracing the five key social commitments adopted by French companies exhibiting paternalism: positive in-migration to under-populated areas, pension schemes, welfare provision, social housing and leisure facilities.

In the $19^{\text {th }}$ century, French industrial paternalism evolved beyond philanthropy as large firms adopted a series of techniques to create and manipulate the hierarchical relations within the management framework (Reid 1985). This mechanism of persuasion and repression to control the workforce created a culture of dependency; moreover, to protect the "insularity of their communities", companies also manipulated local government through overt support for political candidates employed by, or sympathetic to, the company (ibid: p. 585). In France's nationalised mining industry, companies also cited paternalistic benefits as a defence against state interference in the allocation of mineral concessions, the argument being that the impact of their welfare provisions on workers outweighed the potential benefits of returning control of mineral deposits to local communities. Furthermore, companies attempted to retain control over workers through restricting contact with external influences. They established shops with affordable goods that undercut local businesses perceived to be exercising political influence over workers. Foremen were denied the right to establish retail businesses; the companies argued that they needed to control the expenditure of workers, on moral grounds (Reid 1985). Although retail spending was not limited or controlled by Kraoma, no Kraoma managers operated any subsidiary businesses in Briéville. It was not established whether this was by individual choice or in accordance with company policy.

The concept of industrial paternalism is also noted for gender distinctions, which initially succeeded in removing women and children from the workplace, before undergoing a U-turn and positively attracting women back to employment. Some companies in the United States subsequently adopted a social nurturing role, positively grooming 'factory girls' into 'prospective wives' for its male employees (Tone 1997). Kraoma has not proactively pursued any of these strategies; yet, its nepotistic employment practices virtually exclude women from the workplace and restrict the locations and ethnic groups from which employees are recruited. Sharma (2009) found a similar patriarchal culture and gender inequalities in mining towns in Australia where few employment opportunities exist for women and male workers preferred to spend leisure time with workmates, often involving alcohol 
consumption. Such behaviour further marginalised women, strained marital relationships and could affect the social and emotional health of the children.

Bonin (2008) suggests a range of conditions that occurred in the 1940s, during France's socialist period, which curtailed the evolution of paternalism into CSR, despite common roots in welfare. Firstly, reliance on company welfare diminished as France developed state welfare institutions. Moreover, companies lost their influential allies when centralisation of public administration disempowered local government. Additionally, in a stance designed to confront communist unions' ethos, socialist trade unions directly opposed company patronage and control over social development. The statutory role of unions in company welfare also displaced company paternalism through the establishment of Comités d'Entreprise (company social committees), which required companies to commit a percentage of the payroll into a welfare fund controlled by those comités comprising elected employee representatives. Kraoma exhibits many of the characteristics of industrial paternalism and revealed no enthusiasm for embracing the Western notion of CSR that, typically, extends beyond the tangible boundaries of responsibilities towards employees. However, external pressure and reforms to develop paternalism into broader welfare and social initiatives, as experienced in France, are not prevalent in Madagascar. There is no welfare state provision; the role of unions in socioeconomic development is under-developed due to a lack of resources; and, through poor relations with government agencies, the unions have minimal strategic influence. Thus, without significant external influence, Kraoma's paternalism is unlikely to formally extend beyond the tangible boundaries of responsibilities towards employees and ad hoc pastoral care. Moreover, the findings suggest that the paternalistic culture inhibits community involvement in matters which could improve social cohesion or improve the social capital of the community.

Before considering the potential value of union engagement as stakeholders in the EITI process, a global perspective of the influence of the union movement in Africa is offered, followed by an exploration of the potential challenges to unions in developing countries, in the context of the findings of this study. Unions are considered a relatively late development in the social history of Africa, appearing in the 1920s in British colonies and a decade later in French colonial Madagascar (Bureau for Workers' Activities of ILO (ACTRAV-ILO) 2010; Dibben and Nadin 2011). Although union history varies according to former colonial power, postindependence political history and the economic strength of the country, colonial powers generally supported unions, considering them a means to achieving social peace (Henderson 1973). For unions in Francophone Africa, the Brazzaville Conference in 1944 achieved the most significant advancement in terms of social and welfare provision. Although countries were still under colonial control, the 
outcomes of the conference led to greater African empowerment in politics: the freedom to create local associations, as well as negotiating more acceptable working conditions and welfare benefits (Bureau for Workers' Activities of ILO (ACTRAV-ILO) 2010). The following decade, prior to the move to independence for many francophone nations, labour law was revised to permit the establishment of unions that were independent from French parent organisations. Efforts were also made to establish cross-border confederations of African unions, but these failed due to political pressures during the pre-independence period. In the 1950s and 1960s, the union movement played a major role in improving social conditions for workers in Africa, as well as supporting the move for national independence. Solidarity and unity are considered the fundamental strengths that enabled unions to fight for social justice and democracy during the colonial era, as well as supporting the struggle for independence. The key question is whether these characteristics, which could be valuable in terms of consolidating union representation, prevail in the current union movement in Madagascar or other resource-rich developing countries?

Some of the limitations identified in relationships between unions and Kraoma correspond with challenges faced by European unions in the late twentieth century. In the 1960s and early 1970s in Europe, union activity was characterised by militant industrial conflicts, often resulting in strike action for improved pay and conditions. By the late 1970s, collective mobilisation had declined, as had the economy in Europe. Strengthened by former successes, unions gained an enhanced role in determining economic policies with employers and some governments, a period known as "neo-corporatism" (Regini 1992: p. 1-16). Conversely, during this period of union strength in Europe, post-independent African nations sidelined unions or incorporated them as agencies of government. The integration of unions into government was further consolidated during the socialist era experienced by many African nations, including Madagascar (Bureau for Workers' Activities of ILO (ACTRAV-ILO) 2010; Dibben and Nadin 2011). Although structural adjustment programmes strengthened labour laws in Africa, they are broadly thought to have eroded union membership, inter alia, through the reduction in formal employment opportunities (Thomas 1995). In mid-1980s Europe, unions responded to the changing political and industrial conditions by developing greater flexibility. Relationships between unions and management evolved to respond to the diversification of labour, which required individual solutions rather than the aggregated approach of previous eras. In the 1990s, the union movement in Africa regained limited independence through the emergence of more democratic political regimes in Africa, although many governments continued to undermine unions' rights and freedoms. One significant difference appeared between union 
movements in Francophone Africa and those in English-speaking countries: trade union pluralism was fully reinstated in the former, whereas the latter retained a centralised system.

Pluralism, however, has a distinct negative impact on the solidarity and unity, characteristics previously considered critical to consolidating the strength of the union movement. The proliferation of unions, which has evolved under the right to pluralism, is considered one of the most serious challenges to the trade union movement in Francophone Africa (Bureau for Workers' Activities of ILO (ACTRAVILO) 2010). Pluralism, which was introduced to provide a safeguard for the independence of unions has, in effect, enabled the proliferation of unions and facilitated political alliances between unions and political actors. This can lead to loss of union independence and freedom. Although politicisation can provide support for progressing certain union demands through government, it can also result in loss of authority and autonomy (Valenzuela 1992). Pluralism can create the very circumstances it aims to overcome - a case in point being the Democratic Republic of Congo which has 420 unions, mostly emanating from self interest and political ambition rather than true pluralism. Proliferation is not the only problem. A lack of unity and solidarity are other significant issues. For instance, Mali has only two national union centres, but they refuse to collaborate (Bureau for Workers' Activities of ILO (ACTRAV-ILO) 2010). Despite the drawbacks associated with pluralism, the International Labour Organisation (ILO) asserts that workers must have the freedom to join the union they believe will best defend their interests. It also cautions that nations must not return to the one political party-one union position of the socialist era. This study identified that pluralism and the associated politicisation of individual unions restricted solidarity, which impacted on the capacity for the movement to act as a cohesive body of opinion and opposition.

The capacity for Malagasy union voices to be heard is further limited by lack of recognition, suppression and manipulation by senior government officials. The union movement in Madagascar is considered weak for many of the reasons already highlighted: poor organisation, continuing political obstruction and, in multi-sector bodies, the political manipulation of worker representatives (2005; Fleischmann 2009; ITUC 2008). Despite the Government's ratification of international labour law, unions complained to the ILO about repression of their rights, namely, the Government's manipulation of elections for employee representatives and the lack of proper consultation prior to the restructuring of the Board overseeing the Caisse Nationale de Prévoyance Sociale (CNaPS: National Social Security Fund) (International Labour Office 2002). In 2008, the International Trade Union Confederation (ITUC) stated that Malagasy legislation hinders the right to freedom of association and collective bargaining, as well as inhibiting the rights of 'essential' 
public employees to strike (ITUC 2008). More recently, unions lobbied against employers' organisations and the government in a vain attempt to save thousands of jobs in the textile manufacturing sector threatened by international economic sanctions following the political crisis. This lack of success and the resulting massive unemployment almost caused the union movement to collapse. After an initial surge of solidarity in 2009 , the unions remained virtually silent in 2010 , before picking up momentum in 2011 with wage bargaining talks (Andrianasy and Groeger 2011).

As already established, several potentially negative impacts of pluralism, such as proliferation and politicisation, were identified within union dynamics in Kraoma. For instance, the presence of six unions in a company of less than 400 employees, with approximately 50 per cent union membership, provides very few members in the smaller unions. Furthermore, although union activism at the time of this study may undermine members' efforts to substantiate union political neutrality and intraunion solidarity, it also demonstrates the freedom to express opposing views and politics in a relatively open manner.

The challenges associated with community representation in stakeholder engagement initiatives are influenced by dependencies and nepotism that pervade all institutional levels. Thus, the action and behaviour of civil society stakeholder representatives may be unrepresentative of the society they are intended to represent. Similarly, the lack of horizontal and vertical trust and reciprocity inherent in Malagasy society engenders a culture of low expectations regarding transparency and accountability, which further enables a cycle of nepotism and elite rent-seeking behaviour (after Uphoff 1986; Ostrom 1990; Snidal 1995; Grix 2001; Andriamalala and Gardner 2010). These circumstances are further facilitated by the state's low dependence on citizen taxation, which reduces society's ability to bargain with the State to demand the political change or financial transparency that could eliminate rent-seeking behaviour and elicit more equitable distribution of benefits (after Brousseau et al. 2010; Stevens and Dietsche 2008). These societal norms do not progress the purpose or intended outcomes of the EITI, in terms of seeking transparency and accountability. Unions are a notable exception, with a statutory right to collective bargaining in terms of determining employment conditions. Importantly, unions within Kraoma are now questioning the company's lack of transparency and are demanding their legal right to engage in the company's financial and operational decision-making processes. In a country which has experienced numerous political scandals, election irregularities, corruption and violent civil unrest (Ploch, 2009; Randrianja, 2003), this action is a small, but positive, step towards improved governance in one (parastatal) mining company. 
However, as illustrated by Madagascar's history of political coups (Randrianja 2003), the institutional framework in Madagascar conforms to that of a despotic state, whereby groups of elites engage in rent-seeking behaviour until challenged by another group of elites appropriating fewer benefits (after Brousseau et al. 2010; Randrianja 2003). Brousseau et al. (2010) suggest that the process of political development, which includes good governance, relies on two fundamental interrelated dynamics: i) the rule of law, which leads to equalisation of rights; and ii) a capable and impartial state. The authors offer the model of 'constitutionalisation' to describe the process of ongoing vertical interaction, that is, bargaining between heterogeneous groups of citizens, market agents and the ruling elite in order to achieve more equitable rights. The institutional analysis within this paper identified top-level domination and manipulation across several scales. In few instances was bargaining a component of interactions or negotiations, although, in the union movement, external expression of discontent and the drive to improve social capital was becoming more apparent. Traditional respect and low expectations of accountability in leaders had also transposed several scales, from grassroots kinbased elitism to the State and Presidency. Malagasy citizens delegated authority to leaders, despite their questionable legitimacy created by manipulated constitutional processes and the absence of a 'fair' return in terms of public services or equality of opportunity. On the other hand, leaders retained power with minimal vertical delegation or decentralisation of authority among levels of government and directed opportunities towards the elite, often based on personal ties, thus, perpetuating rent-seeking behaviour within the privileged minority.

To conclude, any initiative to promote transparency and accountability, such as a consultative framework, needs to acknowledge and be more responsive to power imbalances and politics at the local level. These conditions can be better understood through improved communication with community representatives who are more equitably selected to accurately reflect the broad range of community opinion. Although pressure from civil society is considered one of the strongest catalysts for institutional reform in resource-rich states, the manipulation of stakeholders in rentier states works against the principles of stakeholder engagement. Rentier states, which derive considerable revenue from non-renewable resources, typically suppress political and institutional reform in order to maintain the conditions of low accountability and lack of transparency that foster rent-seeking behaviour. As a way forward, the process of stakeholder engagement requires a more discerning approach to identifying stakeholders, who can genuinely represent communities with authority, beyond and outside the upward hierarchy of dependency that has been identified within this study. 
(2005). Trade Unions of the World. London, John Harper.

(2007). Fixant les attributions du Ministre de l'Energie et des Mines ainsi que l'organisation générale de son Ministère. Decret N²007-986. L. P. Ministre. Antananarivo, Government of Madagascar.

Andriamalala, G. and Gardner, C. J. (2010). "L'Utilisation du Dina comme Outil de Gouvernance des Ressources Naturelles: Leçons tirés de Velondriake, sud-ouest de Madagascar." Tropical Conservation Science 3(4): 447-472.

Andrianasy, H. and Groeger, S. (2011). Le mouvement syndical à Madagascar. Perspective. Antananarivo, Friedrich-Ebert-Stiftung.

Auty, R. M. (1993). Sustaining Development in Mineral Economies: The Resource Curse Thesis. London, Routledge.

BBC. (2013). "Madagascar holds long-awaited presidential elections." Retrieved 25th October, 2013, from http://www.bbc.co.uk/news/world-africa-24661607.

Beck, T. and Nesmith, C. (2001). "Building on Poor People's Capacities: The case of common property resources in India and West Africa. "World Development 29(1): 119-133.

Bonin, H. (2008). The Prehistory of Corporate Social Responsibility: Why did paternalism fail in France? Institute for Culture Affairs \& European Association for Banking and Financial History Conference Banque de France, Paris, ICCA. 03/08: 11.

Brousseau, E., Schemeil, Y. and Sgard, J. (2010). "Bargaining on law and bureaucracies: A constitutional theory of development." Journal of Comparative Economics 38(3): 253-266.

Bureau for Workers' Activities of ILO (ACTRAV-ILO) (2010). Trade union pluralism and proliferation in French-speaking Africa. Geneva, International Labour Office.

Butler, P. (2004). Tanzania: Liberalisation of Investment and the Mining Sector Analysis of the Content and Certain Implications of the Tanzania 1998 Mining Act. Regulating Mining in Africa: For whose benefit? B. K. Campbell. Uppsala, Sweden, Nordiska Afrikainstitutet: 67-80.

Campbell, B. (2003). "Factoring in Governance is not enough. Mining Codes in Africa, Policy Reform and Corporate Responsibility." Minerals \& Energy, Raw Materials Report 18(3): 2-13.

Campbell, B. K. (2004). The Second Generation of Reformed Mining Codes: Guinea Deregulation and Its consequences for environmental protection. Regulating Mining in Africa: For whose benefit? B. K. Campbell. Uppsala, Sweden, Nordiska Afrikainstitutet: $67-80$. 
Cornell University (2002). Commune Census 2001. I. Programme. New York, Cornell University in conjunction with National Center for Applied Research for Rural Development (FOFIFA) and National Statistical Institute (INSTAT).

Department for International Development (2006). Extractive Industries Transparency Validation Guide, DFID.

Dez, J. (1959). "Chez les Betsimisaraka de la région de Nosy Varika: les Tangalamena." Journal de la Société des Africanistes 29 (2): 229-238.

Dibben, P. and Nadin, S. (2011). "Community Unionism in Africa: The case of Mozambique." Relations Industrielles-Industrial Relations 66(1): 54-73.

Ernst \& Young (2011). Rapport final d'audit et de réconciliation des paiements effectués par les industries extractives à l'Etat malagasy et les recettes reçues par I'Etat pour le compte de l'EITI Madagascar. Extractive Industries Transparency Initiative EITI Madagascar. Antananarivo: 44.

Extractive Industries Transparency Initiative Secretariat (2008). Secretariat Workplan 2008. Oslo, Extractive Industries Transparency Initiative.

Fleischmann, A. (2009). Syndicats et Participation des Travailleurs. Conférence des Travailleurs de Madagascar (CTM), Antananarivo, Friedrich-Ebert-Stiftung (FES).

Graeber, D. (2007). Lost People: Magic and the legacy of slavery in Madagascar. Bloomington, Indiana University Press.

Grix, J. (2001). "Review Article: Social Capital as a Concept in the Social Sciences: The current state of the debate." Democratization 8(3): 189-210.

Grix, J. (2002). "Introducing Students to the Generic Terminology of Social Research." Politics 22(3): 175-186.

Henderson, I. (1973). "Wage-Earners and Political Protest in Colonial Africa: The case of the copperbelt." African Affairs 72(288): 288-299.

Hobley, M. and Shields, D. (2000). The Reality of Trying to Transform Structures and Processes: Forestry in rural livelihoods. Working Paper, Overseas Development Institute: 76.

Huff, A. R. (2010). Representation, Rights and Securities in the Mikea Forest Region of south-western Madagascar. Voices from Madagascar's Forests Improving Representation and Rights of Malagasy Forest Peoples, School of International Development, University of East Anglia, Norwich.

Hyden, G., Court, J. and Mease, K. (2003). Political Society and Governance in 16 Developing Countries. World Governance Survey Discussion Paper. London, ODI: 28. 
International Labour Office (2002). 327th Report of the Committee on Freedom of Association. Geneva, International Labour Office.

ITUC (2008). Internationally Recognised Core Labour Standards in Madagascar. World Trade Organisation (WTO) General Council Review of the Trade Policies of Madagascar Geneva, INTERNATIONAL TRADE UNION CONFEDERATION.

Karl, T. L. (1997). The Paradox of Plenty: Oil Booms and Petro-States. Berkeley, University of California Press.

Kelemen, P. (2006). "Modernising colonialism: The British labour movement and Africa." Journal of Imperial and Commonwealth History 34(2): 223-244.

Kent, J., Williamson, E., Goodenough, T. and Ashcroft, R. (2002). "Social Science Gets the Ethics Treatment: Research governance and ethical review." Sociological Research Online 7(4).

Kolstad, I. and Wiig, A. (2009). Political Economy Models of the Resource Curse: Implications for policy and research. Governance of Africa's Resources Programme: Occasional Paper. Johannesburg, South Africa, South African Institute of International Affairs, University of Witwatersrand: 20.

Kraomita Malagasy S.A. (2010). "Short History of the Company." Retrieved 3rd December, 2008, from http://www.kraoma.mg/engl folder/index eng.htm

http://www.kraoma.mg/engl folder/historique.htm.

ODI (2005). Meeting the Social and Local Performance Standards of International Project Finance Institutions London, Overseas Development Institute.

Ostermiller, S. (2013, 5th October 2013). "Calculator for United States Dollar." Currency Exchange Rate Conversion Retrieved October 5th, 2013, from http://coinmill.com/MGA calculator.html.

Ostrom, E. (1990). Governing the Commons: The evolution of institutions for collective action. Cambridge, Cambridge University Press.

Pearce, F. (2012). The Landgrabbers: The new fight over who owns the Earth, Eden Project Books.

Pegg, S. (2003). Poverty Reduction or Poverty Exacerbation: World Bank Group support for extractive industries in Africa. Washington, DC, Sponsored by Oxfam America, Friends of the Earth-US, Environmental Defense, Catholic Relief Services and the Bank Information Center.

Ploch, L. (2009). Madagascar's 2009 Political Crisis. Washington, Congressional Research Service, US Government. 
Ramamonjisoa, B. (2010). Improving Management of Forest Resources in Madagascar by Reinforcing the Roles of Peasant Communities by a Paradigm Shift in Modes of Knowledge Production. Voices from Madagascar's Forests Improving Representation and Rights of Malagasy Forest Peoples, School of International Development, University of East Anglia, Norwich.

Randrianasolo, J. (2009). Dégâts collatéraux de la crise et impacts de la mondialisation: Les salariés malgaches en pleine difficulté... aujourd'hui l'Afrique. Bagnolet, France, Association Française d'Amitié et de Solidarité avec les Peuples d'Afrique. 112.

Randrianja, S. (2003). "Be Not Afraid, Only Believe: Madagascar 2002." African Affairs, Royal African Society 102: 309 - 329.

Regini, M., Ed. (1992). The Future of Labour Movements. Sage studies in international sociology. London, Sage.

Région Betsiboka. (undated). "Le Relief, Paysages, Pédologie et Géologie." Région Betsiboka Retrieved 3rd May 2011, 2011, from

http://www.betsiboka.gov.mg/index.php?option=com content\&task=view\&id=1\&lte $\underline{\text { mid }=3}$.

Reid, D. (1985). "Industrial Paternalism: Discourse and practice in nineteenth-century French mining and metallurgy." Comparative Studies in Society and History 27: 579607.

Robson, C. (2002). Real World Research: A resource for social scientists and practitioner-researchers. Oxford, Blackwell.

Sarrasin, B. (2009). Mining and Protection of the Environment in Madagascar. Mining in Africa: Regulation and Development. B. K. Campbell. London, Pluto Books: 150 186.

Sharma, S. (2009). "An exploration into the wellbeing of the families living in the 'suburbs in the bush'." Australian and New Zealand Journal of Public Health 33(3): 262-9.

Smith, S. M., Shepherd, D. D. and Dorward, P. T. (2012). "Perspectives on Community Representation within the Extractive Industries Transparency Initiative: Experiences from south-east Madagascar." Resources Policy 37(2): 241-250.

Snidal, D. (1995). Endogenous Actors, Heterogeneity and Institutions. Local commons and global interdependence: heterogeneity and cooperation in two domains. $R$. $O$. Keohane and E. Ostrom. London, Sage: 47-91.

Sobika. (2011). "Ny Havana." Guide Services Retrieved 1st October 2011, 2011, from http://www.sobika.com/sofitrans-nyhavana.html. 
Stevens, P. and Dietsche, E. (2008). "Resource Curse: An analysis of causes, experiences and possible ways forward." Energy Policy 36(1): 56-65.

Talbot, J. (2010). Local Perceptions of External Conservation Efforts in Tsitongambarika. Voices from Madagascar's Forests Improving Representation and Rights of Malagasy Forest Peoples, School of International Development, University of East Anglia, Norwich.

Thomas, H. (1995). Globalization and Third World Trade Unions: The challenge of rapid economic change. London; Atlantic Highlands, N.J, Zed Books.

Tone, A. (1997). The Business of Benevolence: Industrial paternalism in progressive America. Ithaca and London, Cornell University Press.

Uphoff, N. (1986). Local Institutions and Participation for Sustainable Development. Gatekeeper Series. London, International Institute for Environment and Development.

Valenzuela, J. S. (1992). Labour Movements and Political Systems. The Future of Labour Movements. M. Regini. London, Sage Publications Ltd.: xii, $275 p$.

World Bank (1998). Project Appraisal Document for a Mining Sector Reform Project. Washington, DC, World Bank.

World Bank (2002). Plan de Gestion Environnementale du Projet de Reforme du Secteur Minier - Phase II. W. Bank. Antananarivo.

World Bank (2003). Madagascar - Mineral Resources Governance Project. Project Information Document. Washington, D.C.. World Bank.

World Bank. (2004, 17th September 2004). "Striking a Better Balance: The World Bank Group and Extractive Industries: World Bank Group management response executive summary." Retrieved 14th June 2008, 2008, from http://go.worldbank.org/PMSHHP27MO.

World Bank (2008). Madagascar: Projects and Programmes. Project information document (PID), appraisal stage. Washington, WBG: Active Projects.

World Bank. (2011). "What is Governance?" Governance in the Middle East and North Africa Retrieved 12 May, 2012, from http://go.worldbank.org/G2CHLXXOQO. 